\title{
DUKUNGAN PEMERINTAH DESA TERHADAP PROBLEM PENDIDIKAN DI MASA PANDEMI COVID-19
}

\author{
Ahmad Fikri Sabiq1, Muhammad Sa'dullah² \\ 1,2Program Pendidikan Agama Islam, Institut Agama Islam Negeri Salatiga, Indonesia \\ Email: ahmadfikrisabiq@gmail.com
}

\begin{abstract}
The purpose of this research is to find out how the government support of Sepakung Village, Banyubiru District, Kab. Semarang towards Distance Learning (PJJ) which has various obstacles so that this research becomes another role model that can be applied. This research uses a qualitative approach, data collection by interview and observation, and descriptive data analysis. During this pandemic, educational institutions in Sepakung, Banyubiru, Kab. Semarang conducts Distance Learning (PJJ) in order to prevent the spread of covid 19. There are many obstacles experienced by teachers, students, and parents in implementing this PJJ, namely difficult internet networks, availability of gadgets / smartphones, less than optimal parental assistance as well as inadequate parental resources. The support provided by the village government of Sepakung is to provide an alternative solution in the form of providing free internet networks for teachers and students. This solution was chosen because the area has not been reached by internet network providers. Internet networks are placed in strategic places. There is some anticipation that the internet network will not be abused by children.
\end{abstract}

Keywords: village government, education problem, COVID-19, pandemic

\begin{abstract}
ABSTRAK
Tujuan dari penelitian ini adalah untuk mengetahui bagaimana dukungan pemerintah Desa Sepakung, Kecamatan Banyubiru, Kab. Semarang terhadap Pembelajaran Jarak Jauh (PJJ) yang memiliki berbagai kendala sehingga penelitian ini menjadi role model yang bisa diterapkan di tempat lain. Penelitian ini merupakan penelitian lapangan dengan metode dan pendekatan kualitatif (field research), pengumpulan data dengan wawancara dan observasi, dan analisis data secara deskriptif. Di masa pandemi ini, lembaga pendidikan yang ada di Desa Sepakung, Kecamatan Banyubiru, Kab. Semarang melakukan Pembelajaran Jarak Jauh (PJJ) dalam rangka mencegah penyebaran covid 19. Ada banyak kendala yang dialami oleh guru, siswa, dan orang tua dalam melaksanakan PJJ ini, yaitu jaringan internet yang sulit, ketersediaan gadget/smartphone, pendampingan orang tua yang kurang maksimal serta sumber daya orang tua yang kurang mumpuni. Dukungan yang diberikan oleh pemerintah desa Sepakung adalah memberikan alternatif solusi berupa pengadaan jaringan internet gratis kepada para guru dan peserta didik. Solusi ini dipilih karena daerah tersebut belum terjangkau provider jaringan internet. Jaringan internet ditempatkan di tempat-tempat strategis. Ada beberapa antisipasi agar jaringan internet tidak disalahgunakan oleh anak-anak.
\end{abstract}

Kata Kunci: pemerintah desa, problem pendidikan, pandemic, COVID-19

\section{PENDAHULUAN}

Pandemi yang disebabkan oleh Corona Virus Disease 19 atau Covid 19 yang terjadi di belahan dunia sejak akhir 2019 lalu menyebabkan perubahan tatanan kehidupan di berbagai sector. Termasuknya sektor pendidikan yang ada di Indonesia ini (Joharudin et al., 2020; Nurkholis, 2020; Sodik, 2020). Sesuai dengan arahan presiden yaitu belajar dari rumah dan bekerja dari rumah, Mendikbud kemudian menindaklanjuti arahan ini melalui Surat Edaran Nomor 4 Tahun

\footnotetext{
* Copyright (c) 2020 Ahmad Fikri Sabiq, Muhammad Sa'dullah

This work is licensed under a Creative Commons Attribution-ShareAlike 4.0 International License.
} 
2020 tentang Pelaksanaan Kebijakan Pendidikan dalam Masa Darurat Penyebaran Corona Virus Disease (Covid-19). Berdasarkan surat edaran tersebut, dari sejak pertengahan bulan Maret lalu, hampir semua bidang pendidikan formal di Indonesia melaksanakan Pembelajaran Jarak Jauh (PJJ). Model pembelajaran semacam ini dilaksanakan dengan tujuan untuk mencegah penyebaran Covid 19 di lingkungan satuan pendidikan.

Secara teknis, model Pembelajaran Jarak Jauh (PJJ) ini dilaksanakan secara beragam dan variatif oleh masing-masing satuan pendidikan sesuai dengan kondisi lokal di daerah tersebut. Ada yang pembelajarannya memakai copian materi yang kemudian diberikan kepada siswa atau disebut sebagai luar jaringan (luring), ada juga yang memanfaatkan gadget atau smartphone dengan berbagai aplikasi komunikasi di dalamnya atau disebut sebagai dalam jaringan (daring), ada juga yang mengkombinasikan keduanya. Namun secara umum, penggunaan gadget/smartphone dalam PJJ ini menjadi penting adanya (Gunawan, 2020). Disebutkan juga bahwa pembelajaran jarak jauh ini juga tidak bisa dipisahkan dari dunia online (Dai, 2020) Disebutkan juga bahwa pandemi yang diakibatkan oleh wabah Covid-19 ini telah menyebabkan pembelajaran online secara serempak. Pembelajaran online telah terjadi hampir di seluruh dunia selama pandemi Covid-19 (Goldschmidt \& Msn, 2020).

Selanjutnya, dinamika serta kendala yang dihadapi pelaku pendidikan baik oleh guru, siswa, ataupun orang tua ini menjadi beragam. Dari guru yang kesulitan mengadakan proses pembelajaran, kesadaran siswa dalam melaksanakan arahan pembelajaran, kesulitan yang dihadapi orang tua dalam mendampingi anaknya belajar, serta terbatasnya sumber daya untuk pelaksanaan PJJ ini seperti ketersediaan gadget, akses internet, dan sebagainya. (Jamaludin, 2020)

Pembelajaran Jarak Jauh (PJJ) adalah sebuah keniscayaan dimana dalam kondisi pandemi ini belum memungkinkan untuk dilaksanakan pembelajaran secara tatap muka. Oleh karenanya, berbagai kendala di atas perlu diberikan alternatif solusi berupa dukungan dari berbagai stakeholder terkait termasuknya pengampu kebijakan di daerah setempat. Salah satu pemerintah desa yang memberikan dukungan terhadap pembelajaran jarak jauh ini adalah di Desa Sepakung, Kecamatan Banyubiru, Kabupaten Semarang. Dukungan yang diberikan pemerintah ini bisa menjadi alternatif solusi bagi masyarakat.

Merujuk dari berbagai penelitian yang sudah ada, disebutkan bahwa sistem pembelajaran online yang dilaksanakan di tengah pandemic Covid-19 ini memiliki berbagai kendala, diantaranya kuota internet yang terbatas dan masih belum familiarnya tenaga pendidik beserta peserta didik dalam mengaplikasikannya. Sehingga perlu adanya upaya khusus yang lebih maksimal untuk mengatasi masalah ini dari semua pihak (Abidin, dkk, 2020). Selain itu, disebutkan pula bahwa pokok permasalahan utama dalam pembelajaran jarak jauh di masa pandemi ini terletak pada ketidaksisapan fasilitas, pengetahuan maupun kurangnya pengalaman. Hal ini membutuhkan waktu untuk beradaptasi dan menyebabkan keterlambatan proses pembelajaran, serta perbedaan kondisi wilayah yang belum kesemuanya dapat dijangkau internet secara menyeluruh. Oleh karenanya, perlu kiranya dilakukan pembaruan model pendidikan yang sesuai dengan kondisi pandemi namun tidak menimbulkan dampak pada proses pembelajaran (Saleh, 2020). Disebutkan pula bahwa hal yang menjadi hambatan adalah orang tua harus menambah waktu untuk mendampingi anak-anak. Sedangkan dari segi guru, guru menjadi melek teknologi dan dituntut untuk belajar banyak hal kususnya pembelajaran berbasis daring (Anugrahana, 2020). Perbedaan dari penelitian yang sudah ada, tulisan ini mengulas alternatif solusi yang bisa diambil oleh 
pemerintah desa atau pemerintah daerah dalam rangka membantu memberikan solusi untuk pembelajaran jarak jauh. Hal ini yang belum pernah diulas oleh berbagai penelitian yang sudah ada karena kebanyakan hanya mengungkap masalah saja tanpa mengurai alternatif solusi.

Penelitian ini bertujuan untuk mengetahui bagaimana dukungan pemerintah desa terhadap Pembelajaran Jarak Jauh (PJJ) yang kemudian bisa menjadi role model untuk dikembangkan di tempat lain. Penelitian ini menjadi penting karena ada beberapa alasan. Pertama, semua siswa di semua jenjang tingkat pendidikan dari berbagai daerah mengalami hal yang sama, yaitu pembelajaran secara jarak jauh. Kedua, kendala-kendala yang ada pada pembelajaran jarak jauh ini dialami oleh siswa, guru, ataupun orang tua yang mendampingi belajar anak-anaknya. Ketiga, desa atau kelurahan di berbagai daerah bisa menerapkan apa yang dilakukan oleh pemerintah desa Sepakung. Meskipun desa atau kelurahan yang lain bisa menerapkan, namun mereka belum memiliki langkah untuk melaksanakan hal tersebut sebagai wujud dukungan terhadap dunia pendidikan di tengah pandemi. Oleh karenanya, kebijakan yang ada di desa Sepakung yang kemudian dikaji dalam penelitian ini bisa menjadi role model bagi daerah yang lain.

\section{METODE PENELITIAN}

Penelitian ini merupakan penelitian lapangan (field research) dengan metode dan pendekatan kualitatif (Cresswell, 2016). Sumber data dalam penelitian ini adalah pemerintah desa, masyarakat, dan guru di desa Sepakung, Kecamatan Banyubiru, Kabupaten Semarang. Teknik pengumpulan data dalam penelitian ini adalah dengan teknik wawancara dan observasi. Wawancara dipilih karena data yang diperoleh berasal dari responden yang diwawancarai. Dikarenakan dalam kondisi pandemi ini, wawancara dilaksanakan secara langsung dan secara tidak langsung melalui sambungan telepon. Observasi juga dipilih karena kondisi lingkungan di tempat penelitian juga menjadi sumber data serta untuk observasi dipakai untuk mencocokkan data yang diperoleh dari wawancara. Sedangkan analisis data adalah dengan analisis deskriptif dengan alur berupa deskripsi dan interpretasi (Sugiarto, 2015). Data yang diperoleh dipetakkan sesuai kategori masing-masing secara deskriptif kemudian diinterpretasikan oleh peneliti.

\section{HASIL DAN PEMBAHASAN}

Pandemi yang disebabkan oleh Coronavirus Disease atau Covid 19 ini begitu besar dampaknya bagi pendidikan. Pembelajaran yang biasanya dilakukan secara tatap muka di sekolah, sekarang menjadi belajar di rumah atau pembelajaran jarak jauh dengan menggunakan berbagai macam aplikasi seperti whatsapp, class room, google meet, zoom, google doc, google from, dan sebagainya (Dewi, 2020). Ada banyak kesiapan dan persiapan yang harus dimiliki dan disiapkan oleh guru ataupun siswa untuk mengikuti pembelajaran jarak jauh ini seperti adanya gadget/smartphone sebagai alat komunikasi serta adanya jaringan internet yang memadai.

Berkaitan dengan pembelajaran jarak jauh ini, penulis pernah melakukan penelitian di sebuah sekolah bahwa ada $40 \%$ orang tua mengaku kesulitan dalam menkondisikan anak-anaknya untuk belajar di rumah. Ada 30\% orang tua terkendala waktu untuk mendampingi anaknya belajar. Dari mereka ada yang yang sibuk bekerja dan ada juga yang tidak bisa membagi waktu karena semua anaknya ada tugas belajar di rumah. Kendala selanjutnya adalah ada $17 \%$ orang tua yang kesulitan dalam memahami materi pelajaran dan kesulitan dalam memberikan penjelasan materi 
kepada anaknya. Selain tiga macam kendala di atas, beberapa kendala lainnya adalah karena ada lingkungan yang kurang mendukung, sumber daya yang kurang mendukung, dan ada orang tua yang kurang sabar dalam mendampingi anak-anaknya (Sabiq, 2020).

Lebih lanjut, Ayang Emiyati dan Harming menyebutkan ada 6 hal yang menjadi dampak dari adanya Covid 19, yaitu pendidikan tidak berjalan maksimal, perekonomian menurun, hubungan sosial dibatasi, dan juga menyebabkan ada kendala bagi orang tua mendampingi anaknya belajar di rumah. Lebih lanjut berkaitan dengan hal poin terakhir ini, Emiyati menjelaskan bahwa kendala yang dihadapi orang tua dalam hal pendampingan kepada anak-anaknya adalah orang tua mengalami kesulitan karena kurangnya penjelasan materi pelajaran, anak-anak lebih percaya guru dari pada orang tua dan terbatasnya fasilitas yang tersedia. Selain itu juga menyebabkan orang tua mengalami stres dan juga banyaknya mengeluarkan biaya untuk membeli paket data (Emiyati \& Harming, 2020).

Bagi para guru, yang semula masih menggunakan metode konvensional dalam mengajar, di masa pandemi ini dituntut untuk bisa melakukan pembelajaran jarak jauh. Hal ini menjadi tantangan tersendiri bagi para guru. Kemudian berkaitan dengan peserta didik yang tidak memiliki gadget/smartphoe, mereka bisa datang ke sekolah untuk meminta tugas dari guru secara langsung dan kemudian dikerjakan di rumah masing-masing.

Selanjutnya, penelitian ini mendeskripsikan tentang dukungan pemerintah desa terhadap dunia pendidikan yang saat ini dilakukan secara jarak jauh, yaitu di Desa Sepakung, Kecamatan Banyubiru, Kab. Semarang, desa ini terdiri dari 12 dusun dengan jumlah penduduk saat ini ada 4.615 jiwa dari 1.399 kepala keluarga (KK). Kondisi masyarakat di Desa Sepakung, rata-rata pekerjaannya adalah sebagai petani. Agama mayoritas adalah Islam, dan kondisi sosial masyarakat masih mengedepankan gotong-royong ala masyarakat desa (Nuri, 2020). Ada tiga sekolah Islam yang berada di Desa Sepakung, yaitu Madrasah Ibtidaiyah (MI) Nurul Huda, Madrasah Ibtidaiyah (MI) Darussalam dan Madrasah Tsanawiyah (MTs) Nurul Huda. Selain sekolah Islam di atas, juga ada satu SD negeri, yaitu SD Negeri Sepakung. Keempat sekolah ini melaksanakan pembelajaran jarak jauh selama masa pandemi Covid 19 ini (Nugroho, 2020).

Tabel 1. Kondisi Sekolah di desa Sepakung

\begin{tabular}{ccccc}
\hline Data Sekolah & $\begin{array}{c}\text { MI Nurul } \\
\text { Huda }\end{array}$ & $\begin{array}{c}\text { MI } \\
\text { Darussalam }\end{array}$ & $\begin{array}{c}\text { MTs Nurul } \\
\text { Huda }\end{array}$ & $\begin{array}{c}\text { SD N } \\
\text { Sepakung }\end{array}$ \\
\hline Jumlah guru & 9 & 8 & 11 & 12 \\
Jumlah siswa & 135 & 120 & 83 & 190 \\
Siswa memiliki smartphone & $60 \%$ & $30 \%$ & $39 \%$ & $55 \%$ \\
Siswa memakai HP orang tua & $20 \%$ & $65 \%$ & $18 \%$ & $30 \%$ \\
\hline
\end{tabular}

Berdasar tabel 1, mengenai pembelajaran jarak jauh yang dilakukan oleh empat sekolah tersebut, ada beberapa kendala yang dialami peserta didik dalam mengikuti pembelajaran jarak jauh ini. Kendala tersebut adalah kendala soal jaringan internet yang sulit, ketersediaan gadget/smartphone, dan pendampingan orang tua yang kurang maksimal atau sumber daya dari orang tua yang kurang mumpuni.

Terkait dengan berbagai permasalah dari dunia pendidikan sebagaimana di atas, penulis kemudian menemukan data bahwa ada dukungan yang dilakukan oleh pemerintah Desa Sepakung, 
Kecamatan Banyubiru, Kabupaten Semarang. Pemerintah desa ini mencoba memberikan alternatif solusi untuk memudahkan masyarakat terutama para siswa-siswi di desanya untuk mengakses pendidikan yang dilakukan dengan cara menyediakan fasilitas internet gratis untuk peserta didik dan guru serta instansi pendidikan. Pemerintah Desa Sepakung menyadari bahwa fasilitas internet ini merupakan salah satu kunci dari pembelajaran jarak jauh dengan cara online melalui gadget/smartphone.

Alasan utama terkait pengadaan jaringan internet ini sebagai alternatif solusi yang diambil oleh pemerintah desa dikarenakan hal pertama kali yang dikeluhkan oleh masyarakat adalah jaringan internet (Nuri, 2020). Hal ini dikarenakan Desa Sepakung berada di daerah pegunungan yang susah jaringan internet. Setelah ada jaringan internet, kemudian orang tua mengupayakan gadget/smartphone untuk dipakai belajar siswa. Jumlah orang tua atau siswa yang sudah memiliki smartphone sekitar $85 \%$. Apabila ada orang tua yang belum memiliki gadget/smartphone, dia bisa meminjamkan kepada tetangga atau saudara untuk sekedar mengakses materi yang disampaikan oleh guru.

Untuk siswa, fasilitas internet dilakukan dengan cara pemberian akun gratis yang diberikan selama jam belajar. Fasilitas ini bisa digunakan oleh peserta didik untuk menunjang pembelajaran jarak jauh. Sedangkan untuk guru, mereka difasilitasi adanya jaringan internet gratis 24 jam selama masa pandemi ini. Fasilitas ini diharapan bisa mengkoordinir siswa dan mudah mencari bahan ajar dari internet (Nuri, 2020).

Peserta didik dari jenjang SD/MI dan MTs dibatasi penggunaan akun hotspot dimulai dari pukul 07.00-12.00. Sedangkan untuk peserta didik jenjang SMA dan mahasiswa bisa mendaftarkan akun pribadi melalui admin internet untuk bisa mendapatkan akun hotspot gratis agar kebutuhan pembelajaran jarak jauh mereka menjadi lancar. Bagi para orang tua bisa terbantukan untuk memfasilitasi anaknya belajar jarak jauh. Kalau biasanya pengawasan dan segala macam pertanyaan tentang pembelajaran tertuju pada guru, maka pada masa seperti ini pertanyaan pembelajaran tertuju pada orang tua sebagai pendamping belajar siswa. Dan orang tua tersebut berbeda-beda tingkat kemampuan SDM-nya. Terlebih lagi bagi orang tua juga perlu membelikan fasilitas gadget/smartphone untuk anaknya sebagai sarana belajar. Jaringan internet atau wifi ini kemudian ditempatkan di sekolah-sekolah dan tempat-tempat strategis yang bisa digunakan oleh anak-anak usia sekolah untuk belajar. Bahkan sebagian jaringan internet juga sudah disalurkan ke rumah-rumah warga masyarakat.

Ada kondisi dan pengalaman berbeda yang dialami oleh siswa dari sebelum adanya dukungan dari pemerintah Desa Sepakung tentang pembelajaran jarak jauh sampai setelah adanya hal ini. Kalau sebelumnya, siswa tidak bisa mengikuti pembelajaran jarak jauh atau belajar online, orang tua prihatin karena anaknya tidak bisa belajar online, dan para guru bingung karena tidak semua siswa terjangkau jaringan internet. Kemudian dengan adanya dukungan dari pemerintah Desa Sepakung melalui fasilitas internet gratis ini para peserta didik menjadi nyaman untuk mengikuti pembelajaran jarak jauh, orang tua bisa mengontrol anak belajar dari rumah, dan para guru dapat mudah memberikan pembelajaran online serta mudah mencari bahan ajar dari internet (Najib, 2020).

Adapun sumber dana yang digunakan oleh pemerintah Desa Sepakung untuk memberikan fasilitas jaringan internet gratis ini berasal dari dana Desa Sepakung sebesar Rp 40.000.000 (empat puluh juta rupiah) dari dana desa tahun anggaran 2020. Dana tersebut digunakan untuk pengadaan 
infra struktur jaringan internet dan biaya bulanan. Kalau dibuat persentase, dana yang dipakai untuk fasilitas jaringan internet ini adalah $4 \%$ dari dana desa yang dimiliki yaitu sekitar Rp 1.000.000.000 (satu miliyar rupiah) dari APBN (Nuri, 2020).

Selanjutnya, agar jaringan internet ini tidak disalahgunakan oleh siswa untuk mengakses hal-hal yang tidak mendidik, ada beberapa antisipasi yang dilakukan oleh pemerintah desa. Pertama, waktu penggunaan jaringan internet untuk siswa dibatasi dari jam 07.00-12.00. Setelah jam tersebut, siswa tidak bisa mengakses lagi kecuali konten-konten yang isinya tentang pendidikan seperti ruang guru, e-learning, whatsapp, dan sebagainya. Kedua, ada orang dewasa yang mendampingi anak-anak selama jam belajar. Harapannya adalah anak-anak tidak mengakses hal-hal negatif yang tidak mendidik. Ketiga, memblokir konten-konten sensitif yang tidak layak diakses oleh anak-anak. (Nuri, 2020)

Kebijakan yang diterapkan oleh pemerintah desa Sepakung, Banyubiru, Kabupaten Semarang ini merupakan langkah alternatif yang bisa memberikan solusi atas masalah-masalah yang dihadapi oleh guru, siswa, dan orang tua selama pembelajaran jarak jauh. Dengan adanya jaringan internet gratis ini, guru bisa lebih mudah untuk mencari sumber pembelajaran dan memberikan materi serta penugasa kepada siswa. Peserta didik selaku objek utama dari pendidikan juga bisa dengan mudah bisa mengakses materi pelajaran yang diberikan oleh guru. Orang tua selaku yang secara langsung mendampingi siswa belajar selama di rumah ini juga dimudahkan.

Dunia internet juga tidak lepas dari sisi positif dan negatif di dalamnya. Ini yang juga harus diwaspadai oleh pemangku kebijakan yang memilih internet sebagai alternatif solusi. Dari pemaparan data di atas, terlihat bahwa pemerintah desa Sepakung sudah mengantisipasi hal tersebut, yaitu dengan memberikan proteksi di server, pembatasan waktu penggunaan, dan pendampingan dari orang yang lebih dewasa ketika anak-anak melaksanakan pembelajaran. Termasuk juga antisipasi yang mengarah kepada kecanduan penggunaan smartphone dengan adanya batasan waktu. Dari berbagai rangkaian kebijakan oleh pemerintah desa Sepakung ini, penulis menyatakan bahwa program ini bisa menjadi role model untuk diterapkan di daerah lain sebagai alternatif solusi terkait kendala-kendala dalam pembelajaran jarak jauh.

\section{SIMPULAN}

Di masa pandemi ini, lembaga pendidikan Islam yakni MI dan MTs yang ada di Desa Sepakung, Kecamatan Banyubiru, Kab. Semarang melakukan Pembelajaran Jarak Jauh (PJJ) dalam rangka mencegah penyebaran covid 19. Ada banyak kendala yang dialami oleh guru, siswa, dan orang tua dalam melaksanakan PJJ ini, yaitu jaringan internet yang sulit, ketersediaan gadget/smartphone, pendampingan orang tua yang kurang maksimal serta sumber daya dari orang tua yang kurang mumpuni. Langkah pemerintah desa Sepakung dalam mendukung PJJ ini adalah dengan cara memberikan alternatif solusi berupa pengadaan jaringan internet gratis untuk dipakai para guru dan peserta didik. Solusi ini dipilih karena daerah tersebut belum terjangkau provider jaringan internet. Jaringan internet ini ditempatkan di tempat-tempat strategis. Pemerintah desa juga sudah mengantisipasi terkait jaringan internet ini agar tidak disalahgunakan oleh anak-anak. 


\section{DAFTAR PUSTAKA}

Abidin, Z, Rumansyah \& Arizona, K. (2020). Pembelajaran Online Berbasis Proyek Salah Satu Solusi Kegiatan Belajar Mengajar di Tengah Pandemi Covid-19. Jurnal Ilmiah Profesi Pendidikan Vol. 5, No. 1, 64-70.

Anugrahana, A. (2020). Hambatan, Solusi dan Harapan: Pembelajaran Daring Selama Masa Pandemi Covid-19 oleh Guru Sekolah Dasar. Scholaria: Jurnal Pendidikan dan Kebudayaan, Vol. 10, No. 3, 282-289.

Dai, D. A. (2020). Online Home Study Plan for Postponed 2020 Spring Semester During the COVID-19 Epidemic: A Case Study of Tangquan Middle School in Nanjing, Jiangsu Province, China. Jiangsu, China.

Dewi, W. A. (2020). Dampak Covid 19 terhadap implementasi Pembelajaran Daring di Sekolah Dasar. Educatif: Jurnal Ilmu Pendidikan Vol. 2, No. 1, 55-61.

Emiyati, A., \& Harming. (2020). Kendala Orang Tua Mendampingi Anak Belajar di Rumah Dalam Menghadapi Situasi Covid 19. Civic-Culture: Jurnal Ilmu Pendidikan PKn dan Sosial Budaya Vol 4,. No. 1 , 8-16.

Firman, \& Rahman, S. R. (2020). Pembelajaran Online di Tengah Pandemi. Indonesian Journal of Educational Science (IJES), Vol. 2, No. 2 , 81-89.

Goldschmidt, K., \& Msn, P. D. (2020). The Covid Pandemic: Technology Use to Support the Wellbeing of Children. Journal of Pediatric Nursing , 3-5.

Gunawan, d. (2020). Variations of Models and Learning Platforms for Prospective Teachers During the COVID-19 Pandemic Period. Indonesian Journal of Teacher Education, Vol. 1, No. 2, 6170.

Herliandry, L. D., \& dkk. (2020). Pembelajaran pada Masa Pandemi Covid 19. Jurnal Teknologi Pendidikan, Vol. 22, No. 1, 65-70.

Hermansyah. (2020). Pembelajaran Daring atau Luring. Dalam G. Indonesia, Pembelajaran Daring Era Pandemi (hal. 49-54). Jombang: Delta Pustaka.

Indahri, Y. (2020). Permasalahan Pembelajaran Jarak Jauh di Era Pandemi. Info Singkat: Pusat Penelitian Badan Keahlian DPR RI, Vo. 12, No. 12 , 13-18.

Jamaludin, D. (2020). Pembelajaran Masa Pandemik Covid-19 Pada Calon Guru. Bandung: UIN Sunan Gunung Jati.

Kemendikbud, Kemenag, Kemenkes, \& Kemendagri. (2020). Panduan Penyelenggaraan Pembelajaran pada Tahun Ajaran 2020/2021 dan Tahun Akademik 2020/2021 di Masa Pandemi Coronavirus Disease.

Kemendikbud. (2020). Surat Edaran Nomor 4 Tahun 2020 Tentang Pelaksanaan Kebijakan Pendidikan dalam Masa Darurat Penyebaran Coronavirus Disease (Covid-19).

Najib, M. (2020, Agustus 2). Warga Sepakung. (M. Sa'dullah, Pewawancara)

Nugroho, W. M. (2020, Agustus 2). Guru. (M. Sa'dullah, Pewawancara)

Nuri, A. (2020, Agustus 2). Kepala Sekolah. (M. Sa'dullah, Pewawancara)

Sabiq, A. F. (2020). Persepsi Orang Tua Siswa tentang Kegiatan Belajar di Rumah sebagai Dampak Penyebaran Covid 19. Civic-Culture: Jurnal Ilmu Pendidikan PKn dan Sosial Budaya, Vol. 4, No. $1,1-7$.

Saleh, AM. (2020) Problematika Kebijakan Pendidikan di Tengah Pandemi dan Dampaknya terhadap Proses Pembelajaran di Indonesia. https://osf.io/pg8ef/download. (Diakses hari Rabu, 14 Oktober 2020)

Sugiarto, E. (2015). Menyusun Proposal Penelitian Kualitatif. Yogyakarta: CV Solusi Distribusi.

Susanti, S. (2020). Covid-19 dan Dilema dalam Pembelajaran Daring. Dalam G. Indonesia, Pembelajaran Daring Era Pandemi (hal. 163-168). Jombang: Delta Pustaka. 